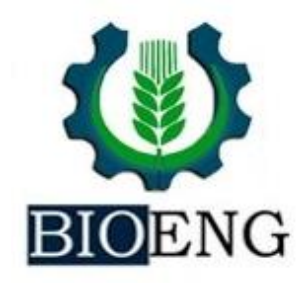

\title{
HEAT STRESS IN BROILERS AND THE NEED OF CLIMATIZATION SYSTEMS
}

\author{
${ }^{1}$ Federal University of Santa Maria, Santa Maria - RS, Brazil \\ ${ }^{2}$ Federal University of Paraná, Curitiba - PR, Brazil
}

Article history: Received 14 June 2017; Received in revised form 24 August 2017; Accepted 04 September 2017; Available online 29 September 2017.

\begin{abstract}
Broilers have better production rates when housed in thermal comfort conditions, outside of this zone the poultry need to maintain homeothermy. The heat production and thermal exchanges are related to body weight and available surface for heat exchange. The genetic evolution of broilers ensured high production with improvement in the feed conversion and reducing the slaughter time. The faster weight gain difficult sensible heat exchange, increasing the needs for climatization systems, in days with high temperatures. Changes in heat waves frequency and days with extreme temperatures are challenging situations for ventilation and evaporative cooling systems in broiler facilities. This review discusses heat exchanges of broilers and the challenges in maintaining the thermal comfort zone in poultry facilities, in a reality of increase of heat stress conditions.
\end{abstract}

Keywords: welfare, heat production, body surface

\section{ESTRESSE POR CALOR EM FRANGOS DE CORTE E A NECESSIDADE DE SISTEMAS DE CLIMATIZAÇÃO}

\begin{abstract}
RESUMO
Frangos de corte apresentam melhores índices produtivos quando alojados em condições de conforto térmico, fora desta faixa necessitam manter a homeotermia. A produção de calor e as trocas térmicas estão relacionadas com o peso corporal da ave e a área de superfície disponível para as trocas térmicas. A evolução genética do frango de corte garantiu maior produção de carne com melhor conversão alimentar e menor tempo para o abate. A evolução do ganho de peso dificultou as trocas térmicas sensíveis aumentando a necessidade de sistemas de climatização, em dias com temperaturas elevadas. Estimativas para mudanças na frequência de ondas de calor e dias com temperaturas extremas são situações de desafio para os sistemas de ventilação e resfriamento evaporativo de aviários. Esta revisão discute as trocas térmicas de frangos de corte e os desafios em manter a zona de conforto térmico nas edificações em uma realidade de aumento de condições causadoras de estresse por calor.
\end{abstract}

Palavras-chave: bem estar, produção de calor, superfície corporal

*mauricioportella@hotmail.com 


\section{INTRODUCTION}

Genetic selection allowed advances in poultry production with the growth rate of broilers from 1957 to 2005 increased $400 \%$, with a simultaneous improvement of $50 \%$ in feed conversion (ZUIDHOF et al., 2014). On the other hand, the genetic improvement worsened the resistance of birds to heat stress. The Red Jungle Fowl (RJF) and Village Fowl (VF) were compared with the commercial broilers with the same weights $(930 \pm 15 \mathrm{~g})$ and submitted to heat stress at $36 \pm 1{ }^{\circ} \mathrm{C}$ for $3 \mathrm{~h}$. The RJF show lower heterophile: lymphocyte ratio, higher plasma corticosterone concentration, and higher heat shock protein 70 expression than VF and commercial broiler (SOLEIMANI et al., 2011; GU et al., 2012). Aggravating this condition, the actual heavier broilers are more susceptible to heat stress increasing the mortality and render more dependent of poultry facilities (VALE et al., 2010).

Poultry heat exchange to the environment depending on the temperature gradient, and may receive or lose thermal energy from environment, through sensible and latent heat exchanges. It represents that in hot environments is necessary to control productive losses due to environment influence and climate changes (NÓBREGA et al., 2011). At regions where high temperatures predominate during most of the year, the control of facility in the internal environment is fundamental to reach thermal comfort zones and improve productive indexes.

The models of climate projections indicate changes in global mean temperature and an increase in high temperatures in the coming years (KNUTTI \& SEDLÁČEK, 2013). Global warming predictions increase the risk of exposure to heat stress, requiring more efficiency to maintain thermal comfort conditions inside the facilities (MENDONÇA, 2006).
This review discusses broilers thermal changes and the challenges to maintaining thermal comfort zone in a reality of increasing risk of heat stress conditions.

\section{Thermal comfort zone and productive performance}

The temperature range in which broilers have the best growth rate is defined as a thermal comfort zone. Out this condition, poultry need spend energy to maintain the homeothermy in detriment of productive performance, reduce protein deposition (OLIVEIRA et al., 2006). Conditions close the thermal comfort zone minimize the energy used for physiological adjustments to the thermoregulation and increasing the energy availability for protein synthesis and deposition (SAKOMURA et al., 2005; CARVALHO FILHO et al., 2006; OLIVEIRA et al., 2006).

Temperature of $36{ }^{\circ} \mathrm{C}$ affects corticosterone levels and heterophile: lymphocyte ratio, acute stress indicators in poultry, increase the release of lactate dehydrogenase, an indicator of organ or tissue injury, and cause oxidative stress by oxygen free radicals in broilers (GU et al., 2012). In heat stress conditions the increase in plasma corticosterone changes the protein turnover, increasing the rate of degradation (catabolism) of the muscle protein, with a consequent increase in heat production due to nitrogen excretion of degraded proteins and worsening in the growth of broilers (QUINTEIRO FILHO et al., 2010).

Prolonged exposures to high temperature and relative air humidity cause physiological and biochemical imbalances, causing productive losses, reduced meat quality and, increase in broilers mortality (PETRACCI et al., 2006; ZHANG et al., 2012). Broilers submitted to $38{ }^{\circ} \mathrm{C}$ increase in the production of blood free radicals due to red cell oxidation (ALTAN 
et al., 2003), acute heat stress at $32{ }^{\circ} \mathrm{C}$ for six hours increases body temperature and induces metabolic alterations and oxidative stress (LIN et al., 2006).

The poultry metabolic body heat can be estimated from body weight (Eq. 1), and more weight promotes more heat production (SALLVIK, 1999). As poultry are homeothermic, with higher heat production, more heat needed to be exchanged with the environment in order to maintain body temperature.

$\Phi_{\text {tot }}=\mathrm{m}^{0.75}$

where:

$\Phi_{\text {tot }}$ - Heat production in Watts;

$\mathrm{m}$ - Poultry weight in $\mathrm{Kg}$.

\section{Heat exchanges}

Poultry body temperature is related with ambient temperature, the birds can receive or lose energy through changes in the behavioral and physiological process, which involves sensible and latent heat exchanges (BORGES et al., 2003; WELKER et al., 2008; NÄÄS et al., 2010).

The sensible heat changes depend on the temperature gradient between the body surface and the ambient temperature, occurring by conduction, convection and, radiation. With a greater body contact area, more efficient the heat changes to the environment. The surface area of broilers as a function of body mass can be estimated from a non-invasive empirical equation (Eq. 2; SILVA et al., 2009).

$\mathrm{Sa}=3.86 \pm 1.06 \mathrm{Bm}^{0.74 \pm 0.01}$

where:

$\mathrm{Sa}-$ Superficial area in $\mathrm{cm}^{2}$;

$\mathrm{Bm}$ - Body mass in $\mathrm{g}$.

The skin surface has a flat distribution while the weight and the body mass have a three-dimensional distribution. As poultry weight gain the produced heat increase, and the surface area for heat exchange is smaller in relation to body volume. From the study of ZUIDHOF et al. (2014) and the application of the equation of SALLVIK (1999; Eq. 1) and SILVA et al. (2009; Eq. 2), is possible to verify that, with genetic selection, broilers gained more weight per time unit, generating more heat and reducing the exchange surface area available to dissipate heat (Figure 1).

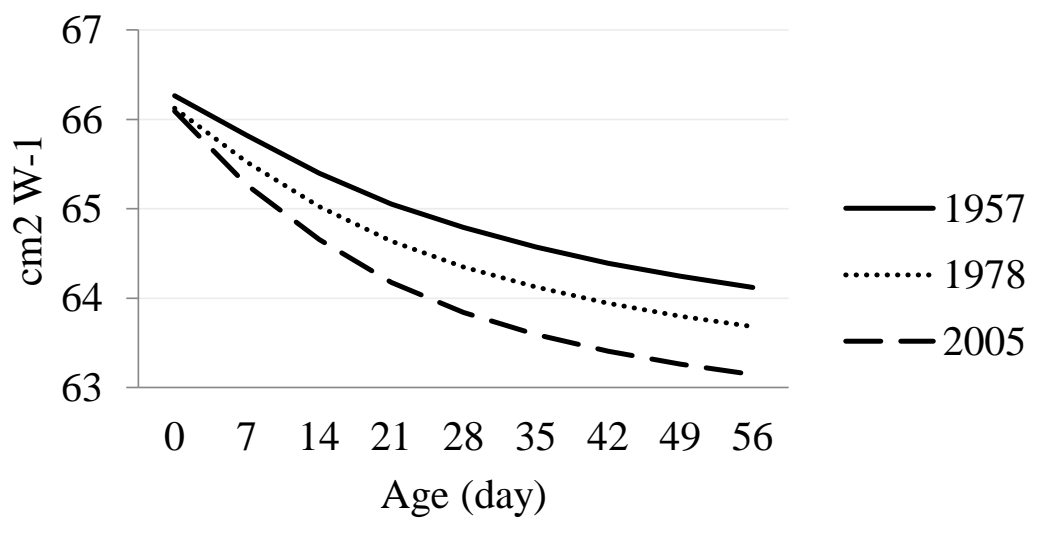

Figure 1. Estimative of total body heat production in Watt per $\mathrm{cm}^{2}$ of body surface in broilers lineages from 1957, 1978 and, 2005 at 56 days of age (ZUIDHOF et al., 2014; SALLVIK, 1999; and SILVA et al., 2009)

The Watt ratio produced by body area varies less in the poorly improved birds (lineage of 1957, Figure 1) which depend less on the cooling conditions of 
housing environment compared to 2005 broilers.

At 30 days of age, the broiler completes feathering, difficult heat changes due to greater insulation in feathered areas (CANGAR et al., 2008; NÄÄS et al., 2010), requiring expansion of latent heat exchanges in heat stress conditions.

At high temperatures, above $35{ }^{\circ} \mathrm{C}$, the principal means of broilers dissipate heat is evaporation (SANTOS et al., 2009). The poultry efficiency to lose latent heat decreases with the increase in air relative humidity, independent of environment temperature, and the exchanges can be zero in environments with $90 \%$ air relative humidity and temperatures of 30 to $35{ }^{\circ} \mathrm{C}$ (GENÇ \& PORTIER, 2005 ).

Temperature and Humidity Index (THI) is a comfort index that can express animal wellbeing relate to temperature and air relative humidity. The THI, proposed by Chepete et al. (2005), considers comfort changes with broilers age, in two periods. The first corresponds to an equation from three to four weeks of age (Eq. 3) and the second, an equation from five to six weeks (Eq. 4).

$$
\mathrm{THI}_{3-4 \mathrm{~s}}=0.62 \mathrm{~T}_{\mathrm{db}}+0.38 \mathrm{~T}_{\mathrm{wb}}
$$

$\mathrm{THI}_{5-6 \mathrm{~s}}=0.71 \mathrm{~T}_{\mathrm{db}}+0.29 \mathrm{~T}_{\mathrm{wb}}$

where:

$\mathrm{T}_{\mathrm{db}}$ - Dry bulb temperature $\left({ }^{\circ} \mathrm{C}\right)$;

$\mathrm{T}_{\mathrm{wb}}-$ Wet bulb temperature $\left({ }^{\circ} \mathrm{C}\right)$;

There is a reduction of 38 to $29 \%$ in the THI equation of wet bulb temperature participation in the broiler comfort between three to four and five to six weeks of age, respectively (CHEPETE et al. 2005). This represents more difficulty of latent exchange heat and, more participation of dry bulb temperature in broilers comfort.

In large poultry flocks, mortality is an important indicator of heat impact. The mean THI higher than $23{ }^{\circ} \mathrm{C}$ increases mortality in broilers with more than 28 days housed in facilities without climatization system (VALE et al., 2008). In facilities with minimum climatization system (ventilation and nebulization), need more severe environment condition, with THI above $30.6{ }^{\circ} \mathrm{C}$. A minimum climatization system allows a better comfort of broilers and, in this system, the external maximum temperatures should less than $34.4{ }^{\circ} \mathrm{C}$ of THI to avoid high mortality in broilers between 30 and 40 days of age (VALE et al. 2010). The values of mentioned studies are important because refer values measured in meteorological stations between one to 45 $\mathrm{km}$ near the broilers farms indicating the possibility to monitor flock by meteorological forecasting.

\section{Temperature reduction potential}

Poultry production facilities were physically adapted, especially in hot places. Characteristics such geographic location, roof type, outside roof color, tree shading, and others, influence the thermal insulation, given more independency of external conditions (ALVES et al., 2004; LIMA et al., 2009; SARMENTO et al., 2005).

In poultry houses with adequate thermal insulation, air renewal is more required on days with outside temperature above broiler comfort, necessary to maintain air quality, control temperature and, increase convection heat loss (CURI et al., 2014). The entrance of hot air into poultry facility, above broilers comfort temperature, requires evaporative cooling systems combined with positive or negative mechanical ventilation systems.

Positive ventilation and cooling systems in poultry facilities aggregate axial ventilators and nebulizers (WELKER et al., 2008). In negative pressure ventilation systems air enters at one extreme with evaporative panels and exits at the opposite side through exhaust fans. Negative pressure systems are more efficient in 
relation to environmental variables uniformity (BUENO \& ROSSI, 2006).

The temperature reduction potential (TRP) of an evaporative system is measured by efficiency in approaching dry bulb temperature $\left(\mathrm{T}_{\mathrm{db}}\right)$ to wet bulb temperature $\left(\mathrm{T}_{\mathrm{wb}}\right) . \mathrm{T}_{\mathrm{wb}}$ is lower or equal to $\mathrm{T}_{\mathrm{db}}$, due transfer heat, which occurs by change water physical state, are required 600 calories to convert $1 \mathrm{~g}$ of water to water vapor at $0{ }^{\circ} \mathrm{C}$ or, 540 calories at 100 ${ }^{\circ} \mathrm{C}$ per g of evaporated water.

The difference between $T_{w b}$ and $T_{d b}$ is defined as wet bulb depression (WBD), equivalent to the total potential $(100 \%)$ that an evaporative cooling system can reduce the temperature. The TRP calculation of evaporative panels allows estimate the efficiencies of adiabatic evaporative cooling systems in percentage by equation 5 (DAG ${ }^{\sim}$ TEKIN et al., 2009)

$T R P=\left(T_{d b} e-T_{d b} l\right) /\left(T_{d b} e-T_{w b} e\right)_{x} 100$

where:

$\mathrm{T}_{\mathrm{db}} \mathrm{e}$ - dry bulb temperature entering the panel;

$\mathrm{T}_{\mathrm{db}} 1$ - dry bulb temperature leaving the panel;

$\mathrm{T}_{\mathrm{wb}} \mathrm{e}-$ wet bulb temperature that enters the panel.

This equation makes possible estimate the vulnerability of a cooling system in face of climatological normals and weather forecasts. Are few knowledge about cooling systems behavior in commercial broiler facilities in extreme heat conditions.

The vulnerability of older broilers to heat stress is high in most tropical and intertropical areas in most of the year,

\section{FINAL CONSIDERATIONS}

The evolution in poultry production guaranteed higher weight gains, however, difficult sensible heat changes requiring better environmental conditions in poultry facilities. aggravated by estimates for changes in the frequency of heat waves (IPCC, 2007; COUMOU et al., 2013), which will require more evaporative cooling systems.

Heat waves are uncomfortable and excessively hot periods, at least two days with maximum temperature above $32{ }^{\circ} \mathrm{C}$, and may last several days or weeks (INMET, 2017). For broilers, successive days with THI greater than $23{ }^{\circ} \mathrm{C}$ already trigger high mortality (VALE et al., 2008), however, a single day with facility inside temperature higher than $32{ }^{\circ} \mathrm{C}$ is sufficient to cause high mortality (VALE et al., 2010).

Among the 16 hottest years since 1880,15 of these have occurred since 2001 , being the hottest in 2015. Projections for the $21^{\mathrm{st}}$ century increase occurrence of heat waves (NOAA / NASA, 2016). The temporal persistence of high temperatures in warmer regions raise up the frequency of extreme temperatures, reflecting on high mortality risk (SALGADO \& NÄÄS, 2010).

Climate changes, in most part, can occur during the winter and transition seasons tending to warmer nights, raising the minimum temperatures, with a high risk of heat waves (MARENGO \& VALVERDE, 2007). Poultry better adapts to daily high maximum temperatures when the temperature in the night falls at $25^{\circ} \mathrm{C}$ or lower. With warmer nights recovery are slower and the next extreme temperature day may a great risk (BALNAVE, 1998).

The dynamics of the typologies and thermal inertia of broilers facility options should be studied and allow a better understanding of thermal insulation, with evaporative cooling systems.

The principal means to control the temperature in poultry houses are ventilation and evaporative cooling systems, with limitations dependent on air relative humidity. 
It will be necessary more efficient climatization systems due to the increase in

\section{REFERENCES}

\begin{abstract}
ALTAN, Ö.; PABUÇCUOĞLU, A.; ALTAN, A.; KONYALIOĞLU, S.; BAYRAKTAR, H. Effect of heat stress on oxidative stress, lipid peroxidation and some stress parameters in broilers. British Poultry Science, London, v.44, n.4, p.545550, 2003.
\end{abstract}

ALVES, S. P.; RODRIGUES, E. H. V. Sombreamento arbóreo e orientação de instalações avícolas. Engenharia Agrícola, v.24, p.241-245, 2004.

BALNAVE, W.L. Increase utilization of sensible heat loss mechanisms in high temperature, high humidity conditions. Word's Poultry Science Journal, v.54, p.69-72, 1998.

BORGES, S.A.; MAIORKA, A.; SILVA, A.V.F. Fisiologia do estresse calórico e a utilização de eletrólitos em frangos de corte. Ciência Rural. Santa Maria, v.33, n. 5, p. 975-981, set- out. 2003.

BUENO, L. G. F.; ROSSI, L. A. Comparação entre tecnologias de climatização para criação de frangos quanto a energia, ambiência e produtividade. Revista Brasileira de Engenharia Agrícola e Ambiental, v.10, p.497-504, 2006.

CANGAR, Ö.; AERTS, J-M.; BUYSE, J.; BERCKMANS, D. Quantification of the spatial distribution of surface temperatures of broilers. Poultry Science, v.87, p.24932499, 2008.

CARVALHO FILHO, D. U.; FIGUEIRÊDO, A. V.; LOPES, J. B.; ALMENDRA, S. N. O.; COSTA, E. M. S.; GOMES, P. E. B.; MERVAL, R. R. Dietas com fitase para frangos de corte alojados em ambientes com diferentes sistemas de climatização. Revista Brasileira de Ciência Veterinária, v. 22, p. 180-187, 2015. heat waves incidence

CHEPETE, H.J.; CHIMBOMBI, E.M.; TSHEKO, R. Production performance and temperature humidity index of broilers reared in naturally ventilated houses in Botswana. Botswana Journal of Agriculture and Applied Sciences, v.1, p.19-28, 2005.

COUMOU, D.; ROBINSON, A. Historic and future increase in the global land area affected by monthly heat extremes. Environmental Research Letters, v.8, 2013.

CURI, T. M. R. C.; VERCELLINO, R. DO A.; MASSARI, J. M.; SOUZA, I. M.; MOURA, D. J. Geoestatística para a avaliação do controle ambiental do sistema de ventilação em instalações comerciais para frangos de corte. Engenharia Agrícola, v.34, p. 1062-1074, 2014.

DAGTEKIN, M.; KARACA, C.; YILDIZ, Y. Performance characteristics of a pad evaporative cooling system in a broiler house in a Mediterranean climate. Biosystems Engineering, n.103, p.100104, 2009.

GENÇ, L.; PORTIER, K. M. Sensible and Latent Heat Productions from Broilers in Laboratory Conditions. Turkish Journal of Veterinary e Animal Sciences, n.29, p.635-643, 2005.

GU, X. H.; HAO, Y.; WANG, X. L. Overexpression of heat shock protein 70 and its relationship to intestine under acute heat stress in broilers: Intestinal oxidative stress. Poultry Science, v.91, p.790-799, 2012.

INMET, ISTITUTO NACIONAL DE METEOROLOGIA, BR. Glossário. 2017. Disponível em: http://www.inmet.gov.br/informacoes/glos sario/glossario.html. Acesso em: 27 jan. 2017. 
INTERGOVERNMENTAL PANEL ON CLIMATE CHANGE, IPCC Mudança do Clima 2007: A Base das Ciências Físicas: Contribuição do Grupo de Trabalho I ao Quarto Relatório de Avaliação do Painel Intergovernamental sobre Mudança do Clima. 25 p., 2007. Disponível em: http://www.ipcc.ch/pdf/reports-nonUNtranslations/portuguese/ar4-wg1-spm.pdf . Acesso em: 14 jan. 2015.

KNUTTI, R.; SEDLÁČEK, J. Robustness and uncertainties in the new CMIP5 climate model projections. Nature Climate Change, v. 3, p. 369-373, 2013.

LIMA, K. R. S.; ALVES, J. A. K.; ARAÚJO, C. V.; MANNO, M. C.; JESUS, M. L. C. DE; FERNANDES, D. L.; TAVARES, F. Avaliação do ambiente térmico interno em galpões de frango de corte com diferentes materiais de cobertura na mesorregião metropolitana de Belém. Revista Ciência Agrária, v.51, p.37-50, 2009.

LIN, H.; SUI, S. J.; JIAO, H. C.; BUYSE, J.,; DECUYPERE, E.. Impaired development of broiler chickens by stress mimicked by corticosterone exposure. Comparative Biochemistry and Physiology Part A: Molecular \& Integrative Physiology, 143(3), 400-405, 2006.

MARENGO, J. A. \& VALVERDE, M. C. Caracterização do clima no Século XX e Cenário de Mudanças de clima para o Brasil no Século XXI usando os modelos do IPCC-AR4. Revista Multiciência, v.8, 2007.

MENDONÇA, F. Aquecimento global e suas manifestações regionais e locais: alguns indicadores da região sul do Brasil. Revista Brasileira de Climatologia, v.2, p.71-86, 2006.

NÄÄS, I. DE A.; ROMANINI, C. E. B.; NEVES, D. P.; NASCIMENTO, G. R.; VERCELLINO, R. A. Broiler surface temperature distribution of 42 day old chickens. Scientia Agricola, v.67, p.497502, 2010.

NOAA / NASA. Thomas R. Karl \& Gavin A. Schmidt. Annual Global Analysis for 2015. Publicação on line janeiro de 2016. Disponível em: http://www.nasa.gov/sites/default/files/ato ms/files/noaa_nasa_global_analysis_2015. pdf. Acesso em 13/02/2016.

NÓBREGA, G. H.; SILVA, E. M. N.; SOUZA, B. B.; MANGUEIRA, J. M. A produção animal sobre a influência do ambiente nas condições do semiárido nordestino. Revista Verde de Agroecologia e Desenvolvimento Sustentável, v.6, p. 67-73, 2011.

OLIVEIRA, R. F. M.; DONZELE, J. L.; ABREU, M. L. T.; FERREIRA, R. A.; VAZ, R. G. M. V.; CELLA, P. S. Efeitos da temperatura e da umidade relativa sobre o desempenho e o rendimento de cortes nobres de frangos de corte de 1 a 49 dias de idade. Revista Brasileira de Zootecnia, v.35, p.797-803, 2006.

PETRACCI, M., BIANCHI, M., CAVANI, C., GASPARI, P. \& LAVAZZA, A. Preslaughter mortality in broiler chickens, turkeys and spent hens under commercial slaughtering. Poultry Science, v.85, p.1660-1664, 2006.

QUINTEIRO FILHO, W.M.; RIBEIRO, A.; FERRAZ DE PAULA, V.; PINHEIRO, M.L.; SAKAI, M.; SÁ, L.R.M.; FERREIRA, A.J.P.; PALERMO NETO, J. Heat stress impairs performance parameters, induces intestinal injury, and decreases macrophage activity in broiler chickens. Poultry Science, v. 89, n. 9, p. 1905-1914, 2010.

SAKOMURA, N.K.; LONGO, F.A.; OVIEDO-RONDÓN, E.O. et al. Modeling energy utilization and growth parameter description for broiler chickens. Poultry Science, v.84, p.1363-1369, 2005.

SALGADO, D.D. \& NÄÄS, I.A. Avaliação de risco à produção de frango de corte do estado de São Paulo em função da 
temperatura ambiente. Engenharia Agrícola, v.30, p.367-376, 2010.

SALLVIK, K. Animal Environment Requirements. In: CIGR Handbook of Agricultural Engineering - Animal Production e Aquacultural Engineering. ASAE Publisher, p.31-41, 1999.

SANTOS, P.A.; BAÊTA, F.C.; TINÔCO, I.F.F.; ALBINO, L.F.T.; CECON, P.R. Ventilação em modos túnel e lateral em galpões avícolas e seus efeitos no conforto térmico, na qualidade do ar e no desempenho das aves. Revista CERES, v.56, p.172-180, 2009.

SARMENTO, L. G. V.; DANTAS, R. T.; FURTADO, D. A.; NASCIMENTO, J. W. B.; SILVA, J. H. V. Efeito da pintura externa do telhado sobre o ambiente climático e o desempenho de frangos de corte. Agropecuária Técnica, v.26, p.117122, 2005.

SILVA, E.; YANAGI, T.; BRAGA R. A.; LOPES, M. A.; DAMASCENO, F. A.; SILVA G. C. A. E. Desenvolvimento e validação de um modelo matemático para o cálculo da área superficial de frangos de corte. Engenharia Agrícola, v.29, p.1-7, 2009.

SOLEIMANI, A. F.; ZULKIFLI, I.; OMAR, A. R.; RAHA, A. R. Physiological responses of 3 chicken breeds to acute heat stress. Poultry Science, n. 90, p.14351440, 2011.

VALE, M. M.; MOURA, D. J. DE; NÄÄS, I. A; OLIVEIRA, S. R. M.; RODRIGUES, L. H. A. Data mining to estimate broiler mortality when exposed to heat wave. Scientia Agricola, v.65, p.223-229, 2008.

VALE, M.M.; MOURA D.J.; NÄÄS I.A.; PEREIRA D.F. Heat waves characterization with impact over broilers mortality rates between 29 days old at the slaughter. Brazilian Journal of Poultry Science, v.12, p.279-285, 2010.

WELKER, J. S.; ROSA, A. P.; MOURA, D. J.; MACHADO, L. P.; CATELAN, F.;
UTTPATEL, R. Temperatura corporal de frangos de corte em diferentes sistemas de climatização. Revista Brasileira de Zootecnia, v.37, p.1463-1467, 2008.

ZHANG, Z. Y.; JIA, G. Q.; ZUO, J. J.; ZHANG, Y.; LEI, J.; REN, L.; FENG, D. Y. Effects of constant and cyclic heat stress on muscle metabolism and meat quality of broiler breast fillet and thigh meat. Poultry science, v. 91, n. 11, p. 2931-2937, 2012.

ZUIDHOF, M. J.; SCHNEIDER, B. L.; CARNEY, V. L.; KORVER, D. R.; ROBINSON F. E. Growth, efficiency, and yield of commercial broilers from 1957, 1978, and 2005. Poultry Science, n.93, p.2970-2982, 2014. 